Of all parts of those variable objects which we call organisms, the most variable is the reproductive system ; and the variations may be either in the direction of increased or of diminished fertility. Having, regard, therefore, to all the delicate, complex, and for the most part hidden conditions which determine this double kind of variation within the limits of the reproductive system, there can be no difficulty in granting that variations in the way of greater or less sterility must frequently occur both in plants and animals in a state of nature. Probably, indeed, if we had the means of observing this point, we should find that there is no one variation more common. But, of course, whenever it arises - whether as a result of changed conditions of life, or, as we say, spontaneouslyit immediately becomes extinguished, seeing that the individuals which it affects are less able (if able at all) to propagate the variation. But now, if the variation should be such that, while showing some degree of sterility with the parent form, it continues to be perfectly fertile within the limits of the varietal form, in this case the variation would neither be swamped by intercrossing, nor would it die out on account of sterility. On the contrary, this particular variation would be perpetuated with more certainty than any other variation, whether useful or unuseful. An illustration will serve to render this more clear.

Suppose the variation in the reproductive system is such that the season of flowering or of pairing becomes either advanced or retarded. Whether this variation be, as we say, spontaneous, or due to any change of food, climate, habitat, \&c., does not signify. The only point we need here attend to is that some individuals, living on the same geographical area as the rest of their species, have varied in their reproductive systems so that they are perfectly fertile inter se, while absolutely sterile with all other members of their species. By inheritance there would thus arise a variety living on the same geographical area as its parent form, and yet prevented from intercrossing with that form by a barrier quite as effectual as a thousand miles of ocean: the only difference is that the barrier, instead of being geographical, is physiological.

From this illustration I hope it will be obvious that wherever any variation in the highly variable reproductive system occurs, tending to sterility with the parent form without impairing fertility with the varietal formno matter whether this be due, as here supposed, to a slight change in the season of reproductive activity, or to any other cause-there the physiological barrier in question must interpose, with the result of dividing the species into two parts. And it will be further evident that when such a division is effected, the same conditions are furnished to the origination of new species as are furnished to any part of a species when separated from the rest by geographical barriers or by migration. For now the two sections of the species, even though they be living on the same area, are free to develop distinct histories without mutual intercrossing, or, as I have phrased it, by independent variation.

To state this suggestion in another form. It enables us to regard many, if not most, natural species as the records of variation in the reproductive systems of ancestors. When accidental variations of a non-useful kind occur in any of the other systems or parts of organisms, they are as a rule, immediately extinguished by intercrossing. But whenever they hapjpen to arise in the reproductive system in the way here suggested, they must inevitably tend to be preserved as new natural varieties, or incipient species. At first the difference would only be in respect of the reproductive system; but eventually, on account of independent variation, other differences would supervene, and the new variety would take rank as a true species.

The principle thus briefly sketched in some respects resembles, and in other respects differs from, the principle of natural selection. or survival of the fittest, as I will show later on. For the sake of convenience, therefore, and in order to preserve analogies with already existing terms, I will call this principle Physiological Selection, or Segregation of the Fit.

Before proceeding to state the evidence of the particular kind of variation on which this principle depends, let it be noted that we are not concerned either with its causes or its degrees. Not with its causes, because in this respect the theory of physiological selection is in just the same position as that of natural selection: it is enough for both that the needful variations are provided, without its being incumbent on either to explain the causes which underlie them. Neither are we concerned with the degrees of sterility which the variation in question may in any particular case supply. For whether the degree of sterility with the parent form be originally great or small, the result of it will in the long run be the same : the only difference will be that in the latter case a greater number of generations would be required in order to separate the varietal from the parent form.

(To be continued.)

\section{TROPICAL FRUITS}

$\mathrm{THE}$ present Colonial and Indian Exhibition has developed interest in tropical fruits to an extent not previously known in England; and whatever may be the individual merits of many of the fruits displayed in the colonial market attached to the Exhibition, no one can deny that they afford proof of numerous undeveloped resources of our colonial possessions in a direction hitherto very much undervalued or entirely overlooked. Sir Joseph Hooker, in one of his journals, has remarked that "most tropical fruits are edible, but few are worth eating." But, after all, the merits of many fruits like those of certain wines are only properly appreciated under a concourse of local circumstances which materially affect our verdict. In the tropics the desire for refreshment and for something cooling and piquant is met by a fruit which, at the moment, completely answers the purpose. Transferred to a cooler climate, the same fruit may be entirely out of place, and indeed may be condemned as valueless. As a case in point, the water of a young cocoa-nut, when clear and fresh, taken from the fruit after a long ride in the sun, is most refreshing and wholesome. The same thing tried in the climate of England, and with fruit imported from the tropics, would be nauseous and wholly unpalatable. Similar remarks would apply to the fruit of the mangosteen, the durian, and many others where it is necessary that the fruit should be eaten when just ripe, and where a long journey affects the quality and impairs the delicacy -both being of an evanescent character.

Again, it is necessary to bear in mind how to use certain tropical fruits in order to appreciate them to the best advantage. Owing to the loose manner in which tropical fruits are termed, apples, plums, pears, peaches, \&c., when they are neitber botanically nor intrinsically anything of the sort, there has arisen considerable confusion respecting them. Again, many tropical fruits are suitable only for salads or curries, and should not appear at the dessert table at all. Others are better when preserved or cooked, and they are then both wholesome and well adapted to the wants of the country. There is no good pear (Pyrus communis, L.), as known in England, grown in the tropics, yet we have the name applied to the Alligator or Avocado pear (Persea gratissima, Gart), the anchovy pear (Grias cauliftora, L.), the prickly pear (Opuntia ficus-indica, Webb), and the wooden pear of Australia (Xylomelum pyriforme, Knight). Again, the English apple, although grown in the hills in the tropics, is practically of little value, but the name is as loosely applied as in the case of the pear, and hence fruits as widely apart as the poles in their botanical classi-

r. Lecture given in the Conference Hall, Colonial Exhibition. Revised by the Author. 
fication are grouped together under the general term of apple. To select a few out of many such names, we have the sugar or custard apple (Anona reticulata, L.), the Kei apple (Aberia caffra, H. and S.), the Mammee apple (Mammea americana, L.), the star apple (Chrysophyllum Cainito, L.), the rose apple (Eugenia Iambos, L.), and the golden apple (Spondias lutea, L.). In plums there are the Caffre plum (Harpephyllum caffrum, Bernh.), the coco plum (Chrysobalanus icaco, L.), the hog plum (Spondias mangifera, Pers.), the Chinese date plum (Diospyros kaki, Lin. fil.), the blood plum (Hamatostaphis Barteri, H. K.), and the gray plum of Sierra Leone (Parinarium excelsum, Sabine); and so with the gooseberry, essentially a cold temperate fruit, English colonists have applied the name to such widely-diverging fruits as those of Physalis Peruviana, L. (Cape gooseberry), Peirescia aculeata, Mill (Barbados gooseberry), and Cicca disticha, L. (Utaheite gooseberry).

The so-called Nuts of the Tropics are in a worse state of confusion as regards the common names, and hence it by no means follows that what are imported as nuts belong at all to that category of fruits. The most familiar of tropical nuts is the cocoa-nut (Cocos mucifera, L.), a true nut; but the Para or Brazil nut (Bertholetia excelsa, H. B.) is simply the seed, not nut, which is inclosed in a large globular fruit, almost as large as a 36 -pound cannonball; exactly the same occurs in the case of the Sapucajo nut (Lecythis Zabucajo, Aub.) as well as in the best of these so called tropical nuts, viz. the souari or butter-nut of British Guiana (Caryocar nuciferum, L.). The cashew nut (Anacardium occidentale, L.) is a fruit borne upon a swollen pear-like peduncle, and presents one of the most remarkable instances of growth met in the tropics. The fruit when roasted is esteemed at dessert, and passes in India under the name of "promotion nut." "The Jamaica walnut (Aleurites moluccana, Willd) is the seed of an Euphorbiad, as also the cob-nut (Omphalea triandra, L.).

From the above remarks it will be noticed from what various sources, and from what a diversified range of plants tropical fruits are derived. Also that little dependence can be placed on the common English names applied to these fruits. Where obtainable little objection can, however, be made against adopting the native or aboriginal names of tropical fruits, as in many cases they are sufficiently distinct, and at the same time are associated with circumstances of a local character, which render the name of permanent value. On this account a native or aboriginal name is quite as good, locally, as the scientific name; but of course it loses its value outside its own country. We have incorporated the aboriginal name in the case of the pine-apple (Ananas sativa, L.), and many instances of a similar character are found in the nomenclature of Indian and Chinese fruits.

Although not strictly speaking a tropical fruit, the orange is found in both the eastern and western tropics, and it is the best known of any foreign fruit. Large increase has occurred in the importation of this fruit to England within the last few years, and the present consumption is at the rate of $4 \frac{1}{2}$ million bushels per annum, or equal to a consumption of sixteen oranges per head of population. Of fruits belonging to the same natural order as the orange there are the lemon (Citrus medica, var. Limonum, Brand), not largely grown in the tropics; the shaddock, or pumelo (Citrus decumana, L.), a fruit often 24 inches in circumference; the citron (Citrus medica, Riss.), chiefly used for "candied peel;" and the lime (Citrus medica, var. acida, Brand), which is chiefly known as the West India lime, and largely grown for naking lime juice, raw and concentrated, for the manufacture of citric acid. This West Indian lime should take the entire place of the lemon in the English market, and when used in cooking gives a most piquant and refreshing flavour, not obtainable from any other source.
The banana generally found in the English market is the dwarf Chinese fruit (.Muse Cauendishii, Paxt.). This is smaller and not so yood as the true banana (Musa sapientum, L.), of which there are numerous varieties. The banana chiefly grown for export purposes in the West Indies is called the Martinique banana, a large yellow fruit about 6 to 8 inches long. The Cuban banana is a red-skinned variety, much coarser than the Martinique fruit, and only eaten when very "full," or in the ripe state of an English medlar. A variety of the banana with short thick fruits of very choice quality is called the fig banana, and this is esteemed as the best of the family, and consumed locally. The plantain (Musa paradisiaca, L.), is practically the tropical potato, and is used roasted, boiled, or fried, exactly as we use potatoes in England. At the present time the consumption of bananas in the United Kingdom is comparatively small. Some of the steamers trading with the West Indies are, however, being fitted with refrigerating chambers for carrying tropical fruit, and the banana should soon become as plentiful and as cheap as the orange. It has the merit of being wholesome and nutritious, and is suitable for invalids and young children as well as for dessert purposes.

The pine-apple we have already noticed. This is a deliciously refreshing fruit with healthful juices, and the demand for it is increasing daily. Hitherto, foreign pineapples, which are gradually driving the home-grown fruit out of the market, are obtained in large quantities from the Azores. The further supply will no doubt come from the West Indies, where pine-apples can be grown in the open air as readily and as cheaply as the English farmer can grow beets or turnips. Unfortunately the choice varieties of pine-apples possess, as the growers say, "bad keeping" qualities; but with increased facilities for packing and stowing the fruit, there should be no difficulties of an insurmountable character in the way of bringing over pine-apples from the West Indies in excellent condition. At the colonial market attached to the Colonial and Indian Exhibition pine-apples from Antigua are sold at sixpence each, and we find from the Blue Book Report that the Bahamas export annually, either in a fresh or canned state, pine-apples to the value of 50,0>0l. annually. The mango (Mangifera indica, L.) is the apple of the tropics, and the mango tree is grown and occupies orchards as do apple-trees in England. Although an East Indian tree, it has become thoroughly naturalised in the west, where it spreads by self-sown seedlings over all waste places. Its introduction into Jamaica is thus described by Lunan ("Hortus Jamaicensis," I 8r 4, p. 486) :"This beautiful tree was one of those brought to this island in June 1782 , and taken in a French ship, bound for Hispaniola, by Capt. Marshall, of His Majesty's ship Flora, one of Lord Rodney's squadron. Capt. Rodney, with the approbation of Lord Rodney, deposited the mango plants and a great many others taken in the same vessel in Mr. East's garden (at Gordon Town), where they were cultivated with great assiduity and success, and have now become one of the commonest fruit-trees in Jamaica, in a great number of its varieties." As the mango ripens in July and August, and would come into the English market at a time when our own fruits are plentiful, it is possible it will not be greatly in demand. The best varieties are the Bombay sorts, while in Jamaica one of the plants deposited by Lord Rodney and having a number only, is is still known there and highly esteemed as "No. i I."

The passion fruits, of which there are several species, are highly prized. Of these there are the granadilla (Passiflora quadrangularis, L.), the pomme d'or, or water lemon $(P$. laurifolia, $L)$, the sweet cup $(P$. edulis, L.), and the calabash sweet-cup ( $P$. maliformis, L.).

From the East Indies few if any fruits can be imported to England with success. In fact Ceylon and India have very few fruits which they can easily spare capable of bearing a long sea voyage, and the choice 
fruits of Singapore and the Malay States are still further removed by time and distance.

At the Exhibition there is shown, from India, a small dried apricot (Prunus armeniasa, L.), an important article of food in the Punjaub Himalayas and in the North-west Provinces, which deserves attention as. a probable source of an import trade for the English market. This fruit is known in India as the mish-mush, or "Moon of the Faithful." Dr. Watt remarks that it is largely eaten by all classes, fresh or dried, but chiefly fresh, and sometimes in preserve by Europeans. Sometimes the apricots are pressed together, and rolled out into thin sheets or "moons," 2 or 3 feet in diameter, like a blacksmith's apron. From Afghanistan large quantities of the dried fruit are imported into India, and distributed by trade far into the plains of Bengal. Kew

\section{MORRIS}

\section{MICROSCOPIC ORGANISMS IN AIR AND WATER ${ }^{1}$}

$\mathrm{T}$ IS Report is part of the "Annuaire de l'Observatoire de Montsouris" for the year 1885, and is worthy of careful study at the present time, when bacteriology is recognised as a special and important department of science. These investigations have been carried on at Montsouris since the year 1875 , and through them Dr. Miquel has been enabled to throw much light on the meteorological aspect of the subject-an aspect that has received but little attention from investigators, as compared with the pathological. Every one will acknowledge that in entering upon a new field in scientific investigation it is extremely important that the line of research should proceed upon as broad a basis as possible, and that the work of experimentation and observation should not be confined to one aspect of the new study, however important it may be. Fallacies are sure to arise when any department of science is too narrowly specialised, from want of that more general knowledge which would prevent the adoption of erroneous views. This is especially liable to be the case in bacteriology, in which the objects of study are so minute and yet so widely distributed in nature. Dr. Miquel's researches-important as they are in themselves-are doubly welcome at the present time, as tending to popularise a field in which workers are urgently needed, as well as contributing largely to our knowledge. The example of Paris - the only city in which systematic investigations of the sort are now undertaken-should stimulate other towns which possess properly equipped meteorological laboratories, to conduct observations on the bacterial organisms contained in air, rain, and soil. The results obtained at Montsouris could then be confirmed or confuted by the results obtained at other laboratories under widely different climatic and meteorological conditions, and the enunciation of general laws and principles would in time become possible. We shall endeavour to place before our readers in this article some of the more important results and deductions made from them by Dr. Miquel, from the observations at Montsouris; but it should be distinctly recognised that any conclusions arrived at by Dr. Miquel are applicable only to Paris and its neighbourhood, and cannot at present be accepted as true for other places where the climatic conditions are different.

Tables are given in the Report, showing for each week of the years 1883-84 (a) the average number of bacterial micro-organisms present in a cubic metre of air, $(b)$ the average barometrical pressure, $(c)$ the average temperature of the air, $(d)$ the average state of humidity of the air [percentage of saturation], (e) the amount of rainfall, $(f)$ the electrical state of the air, $(g)$ the direction and

x "Septième Mémoire sur les Organismes Microscopiques de l'Air et des Eaux," par M. le Dr. Miquel, Chef du Service Micrographique à l'Observa-
toire de Montsouris. average velocity of the wind, $(h)$ the average amount of ozone present in the air. From the observations recorded in these tables, Dr. Miquel has arrived at the following conclusions:-(1) An increase in the number of bacterial organisms contained in a cubic metre of air generally takes place when the barometrical pressure is high : this rule is not absolute, but the exceptions are rare. (2) Temperature does not cause such sudden increments; very often, it is true, a large increase in the number of microbes present in the air takes place in summer, but it is important to note that a sustained high temperature causes a manifest lessening in their number. The thermometer is capable of explaining certain seasonal variations, but not the weekly variations. (3) The maximum number of bacterial organisms present in the air corresponds almost always with a low hygrometric condition of the atmosphere; this is explained by the fact that the degree of humidity is always very high during rain, and when the superficial layers of the soil are soaked in water, periods during which the air is always very poor in bacteria. (4) It would appear $a$ priori that the number of bacteria should increase with the strength of the wind, but observation negatives this assumption. A maximum number of microbes is found frequently during periods of calm-when the velocity of the wind is only 5-Io kilometres per hour-and minima have been observed during periods when the velocity of the wind was more than 30 kilometres per hour. (5) The direction of the wind exercises a considerable influence at Montsouris. The greatest number of maxima are noted when the wind is N.E., and the greatest number of minima when the wind is S.W. (6) When the amount of ozone in the air is large, the number of microbes present is small. The north winds blow over from Paris and contain but little ozone. They are rich in microbes. The presence of ozone in the air appears to have the power of destroying bacterial organisms, and, on the contrary, absence of ozone and humidity of the air-unless rain is falling-allow of an increase taking place in their number.

From observations at Montsouris, extending over a period of five years-1880-84-the average number of bacterial organisms in a cubic metre of air is stated to be: in winter 260 , in spring 495 , in summer 650 , in autumn 380 ; the mean annual number being 445 . In February the air is poorest in bacteria [the average of these five years is 165 ]. Towards the midcile of summer the maxima present themselves [July 700].

Observations have also been conducted for a period of four years-1881-84-on the state of the air, as regards bacteria, in the centre of Paris. These observations were made on the air of the Rue de Rivoli, and afford a marked contrast in the number of micro-organisms to the far purer air of Montsouris, a suburb of Paris, and where, it is important to remember, the Observatory is situated in the centre of a park. The average of these four years' observations shows that the air of the Rue de Rivoli contains 3480 bacteria per cubic metre. The seasonal fluctuations are nearly the same as at Montsouris, the minimum being in February ( 1700 ) and the maximum in July (5010). The average number of bacteria present in a cubic metre of air, for the year I88I, was 6295, whilst the average number for 1884 was only 1830 . This enormous decrease-which is observed in the intervening years to a slighter extent-is attributed by Dr. Miquel to the better drainage and scavenging of the city, and to the better cleansing of the gutters and watering of the streets in dry dusty weather, in 1884 than in I881. The death-rate from zymotic diseases--in which are included typhoid fever, small-pox, measles, scarlatina, whooping-cough, diphtheria, dysentery, erysipelas, puerperal fevers, and choleraic diarrhœa of infants--has also fallen very considerably -27 per cent., if increase of population is taken into account-during this period. The death-rate of 